\title{
Louvicourt Mine - a recent mine closure case study
}

\author{
R. Ouellet Golder Associates Ltd, Canada \\ M.P. Filion Teck Resources Limited, Canada \\ M. Edwards Teck Resources Limited, Canada \\ G.W. Davies Teck Resources Limited, Canada
}

\begin{abstract}
The Louvicourt sulphide deposit, located $20 \mathrm{~km}$ east of Val-d'Or, Quebec, was discovered in 1989. Production of copper and zinc concentrates was initiated in 1994 and ceased in 2005 due to exhaustion of the ore body. The ore and some waste rock from mine development were acid-generating. Early in the mine planning, issues related to protection of the environment and to mine closure were considered. To limit environmental impacts related to acid-generating milling residues, it was decided to take advantage of the paste backfill plant by using 55\% of the milling residues to incorporate them in the cemented backfill. The latter was used for ground support in mined stopes.

Sub-aqueous disposal of mill tailings (remaining 45\%) was selected at the project design stage to inhibit acid generation. An artificial pond was built in a suitable area located $8 \mathrm{~km}$ northwest of the mine. The pond is confined by natural topography and dikes. A polishing pond was added to improve final effluent quality. The retained concept involves maintaining the dikes and water cover in perpetuity.

As required by the Quebec Environmental Act, an Environmental Site Assessment was completed following mine closure. Based on results obtained at Louvicourt, $76,000 \mathrm{~m}^{3}$ of backfill material around the infrastructures were contaminated by dust containing copper and zinc due to the routine handling of ore, waste and concentrates. In addition, part of a barren waste pile was slightly acid-generating $\left(66,000 \mathrm{~m}^{3}\right)$. The site was rehabilitated in 2007 by excavating and placing these materials in the underground workings and on an existing acid-generating waste rock pile that remains to be remediated by installing an impervious cover.
\end{abstract}

Five years after mine closure, the water quality at the tailings pond is good and meets the requirements defined by Quebec Directive 019 on the mining industry. Water in the polishing pond meets Quebec fresh water quality criteria (acute toxicity). The tailings impoundment system is proving to be very efficient at preventing acid generation. Over the long-term, it is anticipated that some portions of the site can be returned to the crown.

\section{Introduction}

The Louvicourt base metal deposit is located $400 \mathrm{~km}$ northwest of Montreal and $20 \mathrm{~km}$ east of Val-d'Or, Quebec, Canada. The Louvicourt deposit was discovered by Aur Resources in 1989. Production was initiated in 1994.

Louvicourt Mine was a Joint Venture (JV) operated by Aur Resources Inc. (Aur) (30\% interest). The other partners were Novicourt Inc. (45\% interest) and Teck Resources Limited (Teck) (25\%). Following the takeover of Aur by Teck in 2007, the latter became the operator of Louvicourt Mine with a 55\% interest in the JV.

In July 2005, following 11 years of production, Louvicourt Mine ceased its operation due the exhaustion of mineral reserves. A total of 15.9 million tonnes grading $3.36 \% \mathrm{Cu}, 1.66 \% \mathrm{Zn}, 0.9 \mathrm{~g} / \mathrm{t} \mathrm{Au}$ and $26.75 \mathrm{~g} / \mathrm{t} \mathrm{Ag}$ was mined.

Post closure activities were initiated in 2005 and are still in progress. This paper is a case study of the Louvicourt Mine closure. Legal aspects related to a mine closure in Quebec are presented. Activities related to the dismantling and environmental rehabilitation of the mine site are described. The performance of the 
tailings pond in controlling acid rock drainage (ARD), 16 years after initial residue disposal and five years after the mine closure, is evaluated.

\section{Louvicourt Mine infrastructures}

The Louvicourt Mine infrastructures consisted of the mine site and the tailings storage facility.

At the mine site (Figure 1), the major components were: the concentrator, the production shaft and ore storage bin, the conveyor, the ventilation shaft, the exhaust raise, the office, warehouse and maintenance shops building, the hoist room, the paste backfill plant, the service railroads and rail spur, the electrical sub-station, and the waste rock storage area.

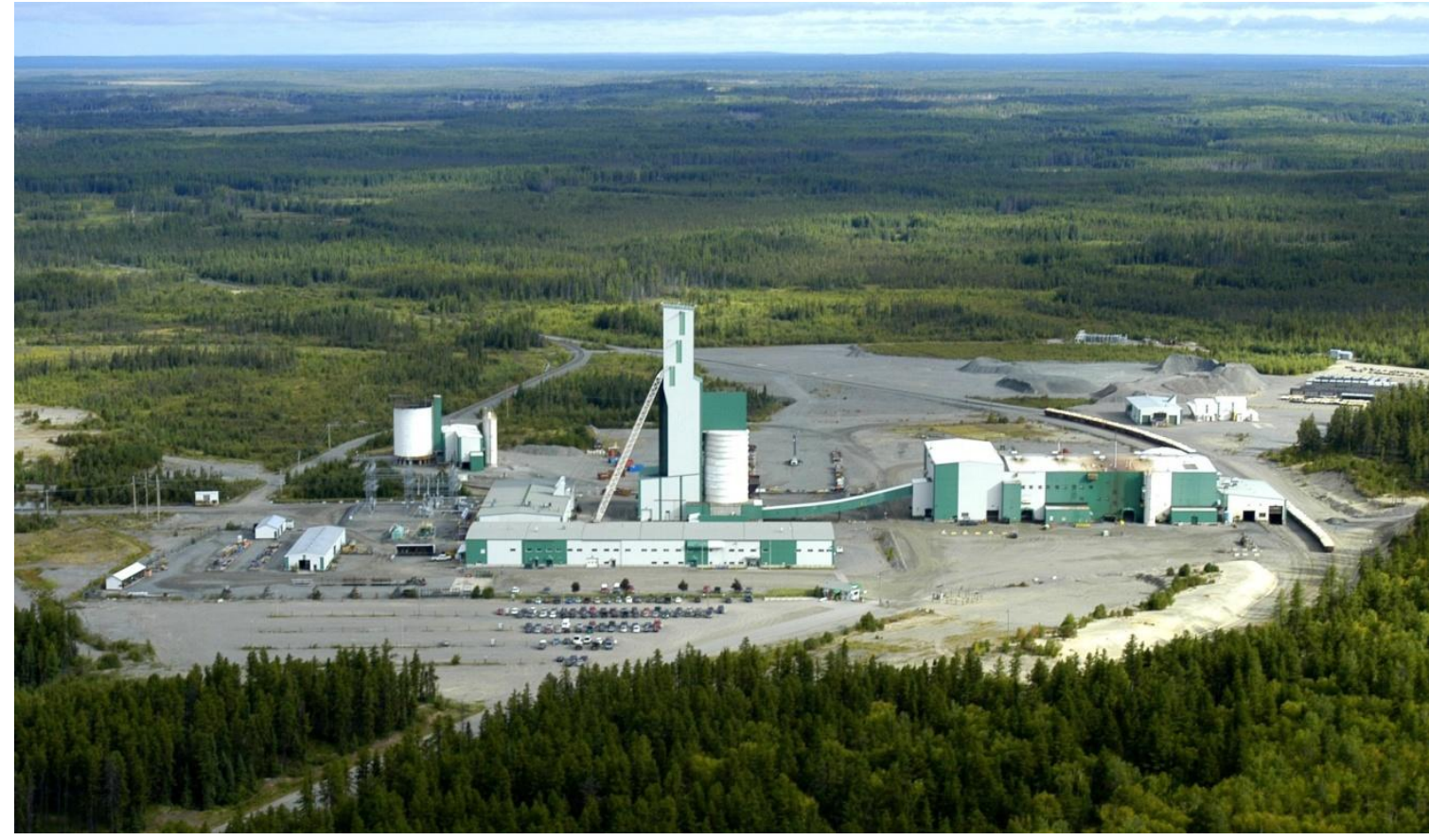

Figure 1 View of the mine site in 2004, before closure (looking north)

Over the southern part of the mine site, backfilling around the buildings and over the parking lot was done using sand and gravel from a nearby borrow pit. Over the northern part of the site, barren mine waste rock was disposed on natural ground to create an open storage area. Waste rock was also stockpiled in this area (northeast).

The tailings storage facility is located $8 \mathrm{~km}$ northwest of the mine site. It consists of a man-made sub-aqueous pond built for retaining the milling residues and of a polishing pond. The tailings pond covers 105.4 hectares and the polishing pond, 20 hectares.

\section{Description of mining operations and residues management}

Louvicourt was an underground mining operation. Ore was mined and brought to surface using the production shaft. It was stored in an ore bin beside the shaft and then conveyed to the concentrator. Using conventional comminution and flotation processes, zinc and copper concentrates were produced. These were sent for treatment in smelters and refineries in Canada.

Early in the mine planning, issues related to protection of the environment and to mine closure were fully integrated into the mine project design using the principle: Design for closure, operate for closure. At the design and construction stage between 1991 and 1993, it was determined that the tailings would have a net acid generation potential (Julien et al., 2003) and would require special consideration in the project design. Milling residues (i.e. tailings) contained mainly pyrite (30-45\%), chlorite (26-53\%), and carbonates $(12-24 \%)$. 
To limit environmental impacts related to acid-generating milling residues, it was decided to take advantage of the paste plant built to produce cemented backfill. The latter was used for ground support in mined stopes; $55 \%$ of the milling residues were used in the production of the paste backfill and were therefore confined in the mine workings. The backfill was a mix of partly dewatered milling residues, cement and ferrous slag. The remaining $45 \%$ of the milling residues were sent to the tailings impoundment, totalling approximately 6.6 million tonnes of sulphide-bearing residues.

At the mine design stage, the tailings storage facility was planned to prevent acid rock drainage (ARD). A man-made structure to retain water was built and used to store residues under a one metre water cover. Continuous submergence of tailings is considered a very effective method of preventing ARD as it cuts oxygen availability to the acid-generating residues, therefore preventing their oxidation and the release of acidity, metals, and sulphates (Yanful et al., 2004). The tailings site selection process required careful consideration of the drainage basin size, site hydrology and meteorology to ensure that a permanent water cover could be maintained after mine operations. Milling residues were transported from the mill to the tailings impoundment via a $30 \mathrm{~cm}$ isolated pipeline constructed along a service road.

The use of both underground disposal and surface sub-aqueous storage of acid-generating residues was considered innovative at the time and Louvicourt Mine was awarded the Prospector and Developers Association of Canada "Environmental Award" in March 1995. The Louvicourt tailings was one of the first Canadian large scale applications of a man-made water cover to prevent ARD.

The tailings pond was also planned to be left as is at mine closure, without the necessity of additional remediation measures to control ARD. The design for closure/operate for closure approach resulted in significant financial savings related to closure.

\section{$4 \quad$ Legal mine closure process in Quebec}

In Quebec, the Environment Quality Act (EQA) requires that "a person who permanently ceases an industrial or commercial activity of a category designated by regulation of the Government is required to perform a characterisation study of the land on which the activity was carried on within six months of the cessation". Mining is an activity regulated by the Quebec Land Protection and Rehabilitation Regulation.

According to the EQA, "If the characterisation study reveals the presence of contaminants in a concentration exceeding the regulatory limit values, the person who carried on the activity concerned is required to transmit for the Minister's approval, as soon as possible after being informed of the presence of the contaminants, a rehabilitation plan setting out the measures that will be implemented to protect human beings, the other living species and the environment in general"'.

The major steps of a mine closure, as required by the EQA, are:

- Environmental Site Assessment (ESA; attested by registered expert).

- Registration of a contamination notice (if contamination is proven).

- Preparation of an environmental rehabilitation plan.

- Obtaining of authorization to carry out rehabilitation work.

- Carrying out of rehabilitation work.

- Preparation of a work completion report (attested by registered expert).

- Release of liability if rehabilitation work proves successful.

- Monitoring if necessary.

All documents need to be submitted to the Ministry of Sustainable Development, Environment, and Parks (MSDEP) for approval. The ESA and the work completion report must be attested by an expert registered with the MSDEP. This whole procedure is intended to deal with land contamination produced by an industrial activity.

Mining activities are also legislated by the Quebec Mining Act (QMA). According to the QMA, land rehabilitation and restoration work must be carried out by every operator who engages in mining operations, 
every person who operates a concentration plant, and every person who engages in mining operations. Before initiating a mining activity, a reclamation plan must be submitted to the Ministry of Natural Resources and Wildlife (MNRW) for approval by the Minister. Land used for disposal of mining residues (including mine waste rock and milling residues) must be remediated to confine contaminants, if present, and to return the site to a natural state.

\section{$5 \quad$ Dismantling of infrastructure}

Following closure of the Louvicourt Mine, dismantling of the buildings and infrastructure was initiated in July 2005 and completed in July 2006. Salvageable underground and surface equipment and goods were sold, as well as the ventilation shaft/hoist, the concentrator, and the office building structure. Metal scrap was sent to a recycling company. Cement and dry wall debris were disposed on the mill foundation and covered with a sand and gravel layer. All other cement foundations were left in place and covered with sand and gravel.

\section{$6 \quad$ Planning and results of the ESA}

The ESAs were requested for the closure of the mine site and the tailings pond. The ESA for the mine site was initiated in November 2005 and completed in November 2006. At the tailings pond, the ESA was carried out from June to November 2006.

The field work for the ESA of the mine site was mostly carried out by drilling 223 boreholes and sampling of soil and backfill (Golder, 2007a). Approximately 700 samples of soil, backfill and sediments were assayed, mostly for metals. Surface water was collected in 3 drainage ditches and assayed. Groundwater was sampled in 29 observation wells and assayed (wells installed within overburden). An extensive trenching program, using a mechanical shovel, was carried out in order to sample and test mine waste rock disposed over the northern part of the mine site. Acid base accounting (ABA) tests were done on 38 waste rock samples and leach tests were completed on 11 composite samples (coming from the 38 samples).

Based on the results of the ESA for the mine site (Golder, 2007a), it was determined that dust coming from routine handling of waste rock, milling residues, ore and concentrates contributed to metal contamination of the sand and gravel material used as backfill around the buildings. Primary contaminants were copper and zinc. Secondary contaminants were arsenic, cadmium, cobalt, manganese, and molybdenum. Copper was the clearest indicator of contamination and was always present if there was metal contamination in a sample. A metal concentration higher than limits listed within Appendix 1 of the Quebec Land Protection and Rehabilitation Regulation is considered as contamination (e.g. $100 \mathrm{mg} / \mathrm{kg}$ for copper and $500 \mathrm{mg} / \mathrm{kg}$ for zinc).

Metal contamination was found around the production shaft, the ore storage bin, the conveyor, the concentrator, the concentrate loading area, the paste backfill plant, and the exhaust raise. Air coming out of this raise contained dust from underground. It was estimated that $76,000 \mathrm{~m}^{3}$ of sand and gravel backfill around the infrastructures and a minor quantity of soils were contaminated by dust containing mostly copper and zinc. Metal contamination was also found in sediments of the drainage ditches surrounding the site. Depth and lateral spreading of metal contamination was limited (usually shallower than $1 \mathrm{~m}$ ).

Over the northern part of the mine site, the waste rock contains metal values above the applicable limits for the site. Waste rock is not considered as soil and the Land Protection and Rehabilitation Regulation does not apply. However, it had to be proven that metals contained in the waste rocks could not be mobilized. Based on the waste rock characterisation program, it was found that a waste rock pile located in the northeast part of the site was slightly acid-generating, as well as a small stretch of road over the west part of the site. Leach tests on the waste rock demonstrated that metals could not be mobilized under neutral $\mathrm{pH}$ and acid rain conditions. Based on the testing program, it was estimated that $66,000 \mathrm{~m}^{3}$ of waste rock were slightly acidgenerating. The rest of the waste rock was considered inert.

Surface water collected in the drainage ditches was not contaminated. Out of the 29 observation wells, water from three locations was found to be contaminated with metals. They are located nearby the acid-generating waste rock pile northeast of the site, close to the concentrate loading area, and along the residue pipeline 
stretching between the mill and the production shaft. Low $\mathrm{pH}$ and high copper, zinc, and sulphates values were typical.

At the tailings impoundment, the ESA covered only the periphery of the ponds and the footprint of the residues pipeline. The tailings storage facility itself is not subjected to the Land Protection and Rehabilitation Regulation since tailings are not soils but mining residues. The objective of the ESA was to verify if residues in the tailings pond contributed to contamination of the surrounding environment. Surface soil samples were collected every $500 \mathrm{~m}$ along the periphery of the tailings and polishing ponds. Metal concentrations were below acceptable limits (Golder, 2010b). During dismantling of the residue pipeline, segments were piled on the road side at about 10 different locations. Some residues still present in the pipeline spilled on the road side at these locations. These spills were cleaned up in October and November 2006. Residues were excavated and disposed within the mine exhaust raise.

\section{$7 \quad$ Rehabilitation of the mine site}

Based on results of the ESA for the mine site, an environmental rehabilitation plan was prepared and submitted to the MSDEP for approval (Golder, 2007b). The plan consisted of excavation and removal of the metal contaminated sand and gravel backfill, including minor quantities of soils and ditch sediments. The plan also provided for excavation and removal of the acid-generating waste rock pile.

Environmental rehabilitation of the mine site was carried out from May to September 2007. Approximately $142,000 \mathrm{~m}^{3}$ of contaminated backfill and waste rock were excavated (Golder, 2010a). As planned and approved by the MSDEP, excavated materials were disposed within the mine production shaft, the ventilation shaft, and the exhaust raise. There was a volume of $60,000 \mathrm{~m}^{3}$ available in these three mine openings. Disposal in mine workings and eventual flooding of these materials will control dispersal of metal contaminants. After excavation, the site was backfilled with sand and gravel and seeded.

The remaining excavated materials were disposed on an acid-generating waste rock pile located $1 \mathrm{~km}$ west of the mine site. Work continues on the design of an impervious cover system for this pile in order to complete the remediation efforts.

Since contaminated backfill and acid-generating waste have been removed from the mine site, it is expected that the quality of groundwater will improve over time.

A ten year environmental monitoring program was initiated in the fall of 2007 , following the site rehabilitation, and is still in progress. Surface water is collected at 3 locations. Groundwater is sampled from nine observation wells. Based on three years of monitoring, the quality of surface water is good. At the three locations where groundwater was contaminated, a gradual improvement is noted, with an increase of $\mathrm{pH}$ and a decrease of copper, zinc, and sulphate concentrations.

\section{Comments on the mine site ESA}

Even though Louvicourt Mine was a modern operation and the site was properly maintained all through the operation period, routine handling of waste rock, ore, and concentrates led to some ground contamination by dust containing metals. The lesson to learn from the Louvicourt closure is that dust control is a key to reduce possible ground contamination in a base metal mine operation.

In addition, some acid-generating waste was found in a pile that was supposed to be inert. A tighter and more rigorous control on chemical properties of waste rocks to be disposed would have most likely reduced rehabilitation costs.

\section{Design of tailings storage facility}

At the design stage, it was estimated that a minimal one metre water cover would be sufficient to prevent ARD generation from milling residues given the size of the pond and the wave action (Julien et al., 2003). After an extensive evaluation of meteorology and hydrology, a one metre water cover depth was selected to ensure that the tailings would remain permanently underwater. A suitable site had to be found to build the tailings pond. An area with a low conductivity foundation, such as clay, compacted till, or bedrock, was required. The selected area also had to show appropriate topography to insure a natural water recharge from 
precipitation, runoff, and seepage of groundwater, in order to naturally maintain the one metre water cover after mine closure. Impervious dikes had to be keyed into natural low conductivity foundation. Dikes had to minimize seepage.

In 1992, a site identification and screening process (Julien et al., 2003) was carried out to find a suitable location for the tailings impoundment. An appropriate site was found $8 \mathrm{~km}$ northeast of the mine site. It was a natural basin bounded to the south by small hills and to the north by elevated bedrock with local outcropping. In order to build the pond that would retain tailings, dikes were constructed to the west, north and east of the natural basin. The pond is bounded to the south and southeast by natural topography. A total of $2.5 \mathrm{~km}$ of dikes was required.

The dikes consist of a minimal $6 \mathrm{~m}$ wide till core with a chimney sand drain along downstream faces (Julien et al., 2003) and sand and gravel shells on both faces. Finger drains were added for evacuation of seepage water. Upstream slopes are $2.5 \mathrm{H}: 1 \mathrm{~V}$ and downstream slopes are $2 \mathrm{H}: 1 \mathrm{~V}$. Dikes are covered with a $0.5 \mathrm{~m}$ thick riprap protection layer. Freeboard was set at $2 \mathrm{~m}$. Berms were added where dikes were higher. Dikes were designed with a 1.4 safety factor under static conditions and 1.1 under seismic loading using a 1:1,000 year earthquake event.

The original design of the tailings facility had a provision for a polishing pond in case the water quality in the tailings pond deteriorated (Julien et al., 2003). In 1994, it was noted that natural oxidation of thiosalts generated by the milling process resulted in acidification of the water. In 1995, the polishing pond was constructed as well as a lime plant located at the tailings pond spillway. The polishing pond is located just east of the tailings pond. It is bordered to the north and west by dikes, and by natural topography to the east and south. Dikes of the polishing pond are similar to those of the tailings pond. During operation of the mine, the $\mathrm{pH}$ was controlled at the tailings pond spillway and within the pond as well. The lime plant was dismantled at mine closure while the polishing remained and continues to ensure water improvement through a retention time in the basin.

Based on the design of the Louvicourt tailings facility, post-closure remediation is not required. However, dike stability and water management structure integrity must be ensured in perpetuity. The dikes and tailings area are inspected on a regular basis and after events such as large storms or earthquakes.

Initial investment for construction of the tailings facility was $C \$ 10,000,000$. Figure 2 shows the infrastructure, with the tailings pond in the background and the polishing pond in the foreground.

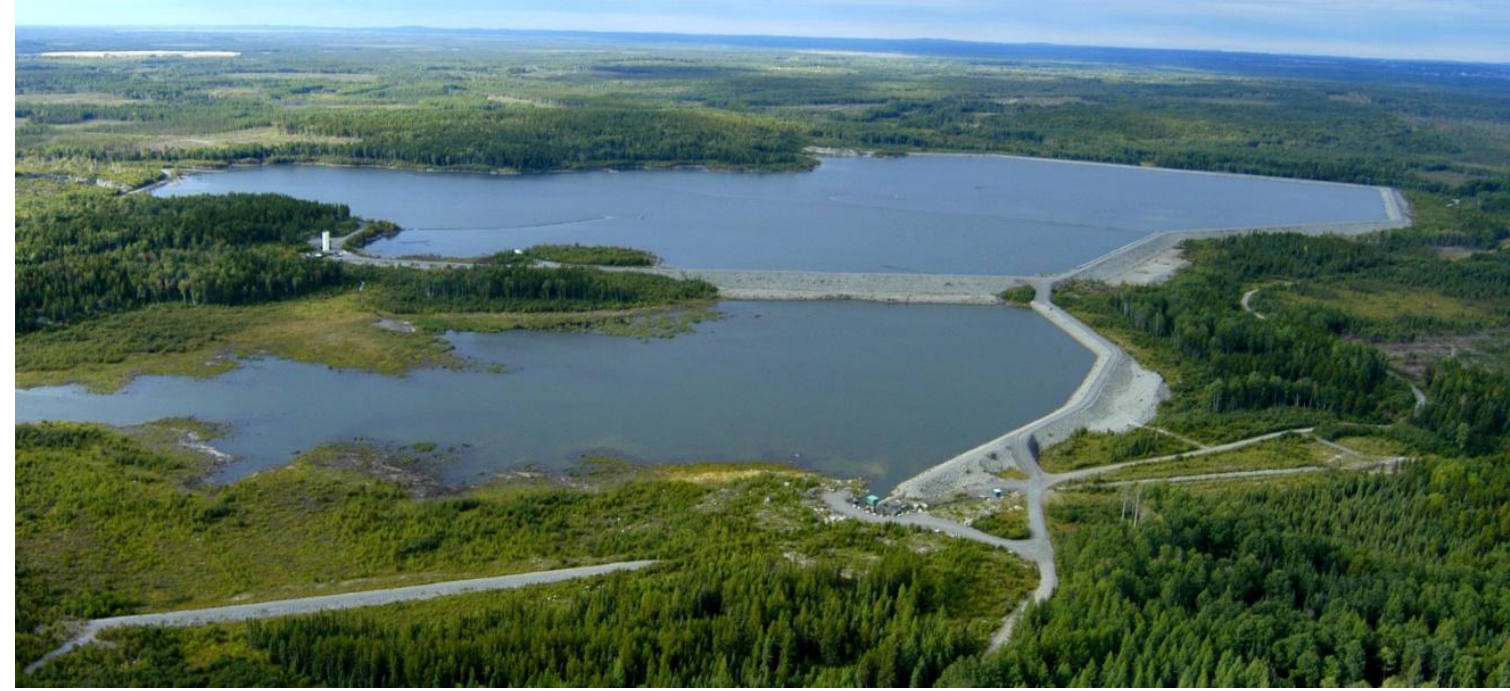

Figure 2 View of the tailings pond infrastructure in 2004 (looking southwest)

\section{Tailings monitoring program}

A monitoring program has been in place since construction of the tailings management facility. Tailings disposal ceased when the mine closed in July 2005. Since then, the geotechnical monitoring program consists of documented monthly routine inspections, annual geotechnical inspections, and dam safety reviews every 
5 years. Quick inspections are carried out every time water sampling is required. Site maintenance is done when required. Vegetation on dikes is removed every three years. Winter inspections are carried out once or twice per winter.

A major issue encountered at the tailings pond is blocking of water management structures by beaver activity. Culverts, spillways, drainage ditches, and surrounding brooks have been blocked fairly quickly in the past by beavers. Monitoring of beaver activity is done during regular visits to the tailings. So far, culverts have had to be removed or unplugged. Beaver dams have had to be partly dismantled on neighbouring brooks. Special attention is required at the tailings spillway, where logs put in place by beavers have to be removed on a regular basis.

An environmental monitoring program is also in place at the tailings pond. Since 2005, groundwater is monitored in six observation wells twice per year. One well is located upstream to the south. Two wells are located downstream to the west of the tailings pond (TP), two are downstream and to the north of the tailings pond, and one is located north of the polishing pond (PP). Four seepage stations are monitored three to four times per year: two stations west (seepages \# $1 \&$ 2), and two stations north of the tailings pond (seepages \# $3 \& 4$ ). The final effluent at the polishing pond is monitored once a week if there is flow. Occasional sampling at the tailings pond spillway is carried out, if there is flow.

Starting in 2011, a new long-term program approved by the MSDEP through a Certificate of Authorization will be implemented. Groundwater will be sampled three times per year in the six observation wells. Surface water at the polishing and tailings ponds spillways, as well as at the four seepage measurement stations, will be sampled and assayed once per month from May to October each year. There will be no sampling during winter. A new surface water station upstream of the polishing pond was established. This station is to monitor the quality of natural water flowing in the polishing pond.

The post-closure environmental monitoring is expected to be maintained for a minimum period of ten years. The program could be stopped after ten years, with MSDEP approval, if water quality proves to be acceptable. The geotechnical and maintenance programs will be maintained in perpetuity.

\section{Results of post-closure monitoring at the tailings pond}

Results of the mine post-closure monitoring data are presented and discussed for the major contaminants. Figure 3 presents a graph of the zinc concentrations at the tailings pond and the polishing pond spillways since 2005 .

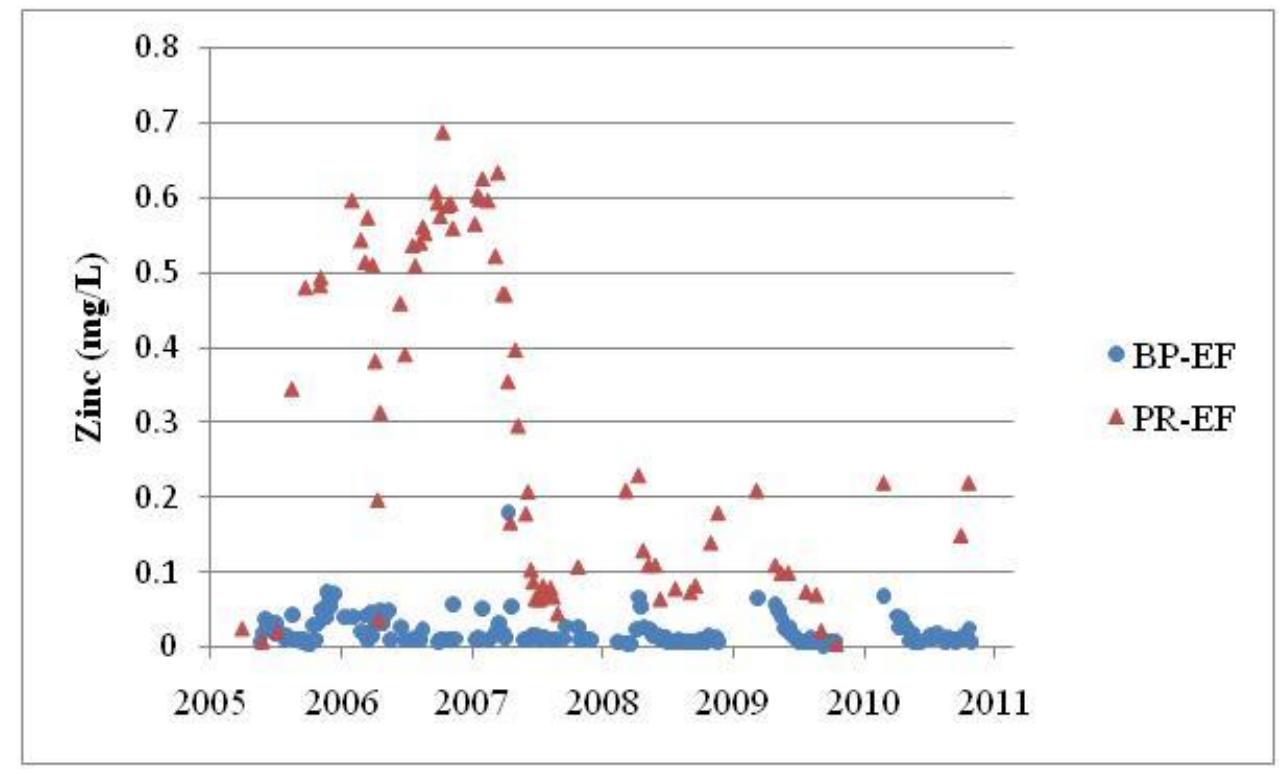




\section{Figure 3 Zinc concentrations in the tailings pond (PR-EF) and the polishing pond (BP-EF) for the 2005-2010 period}

The graph shows that zinc values at the tailings pond have significantly decreased since the mine closure. Late in 2006 and early 2007, zinc concentrations at the tailings pond increased. Water treatment using caustic soda was carried out in the fall of 2006 and the spring of 2007. Since then, zinc concentrations have decreased and remained in the range of $0.2 \mathrm{mg} / \mathrm{L}$ or lower, which is in compliance with Directive 019 on mining industry (MDDEP, 2005), even though the effluent of the tailings pond is not a final effluent and the Directive does not apply. The acceptable monthly average of Directive 019 for zinc is $0.5 \mathrm{mg} / \mathrm{L}$.

The zinc concentrations in the polishing pond final effluent are steady and below $0.1 \mathrm{mg} / \mathrm{L}$ since 2005 . From 2007 to 2010, the polishing pond was closed during winter. Zinc values are slightly higher in the spring when the pond is re-opened. Zinc decreases gradually during summer. Zinc values at the polishing pond effluent are in compliance with Directive 019 and also below Quebec surface water quality criteria, acute toxicity (MDDEP, 2009).

Figure 4 presents a graph of copper values in the tailings pond and the polishing pond spillways since 2005 . Since water treatment in 2006 and 2007, the copper concentration in the tailings pond has decreased and remained steady at or below $0.02 \mathrm{mg} / \mathrm{L}$. The acceptable monthly average of Directive 019 is $0.3 \mathrm{mg} / \mathrm{L}$. In the polishing pond, the copper values have decreased since the mine closure and have been consistently below $0.02 \mathrm{mg} / \mathrm{L}$ since 2008 .

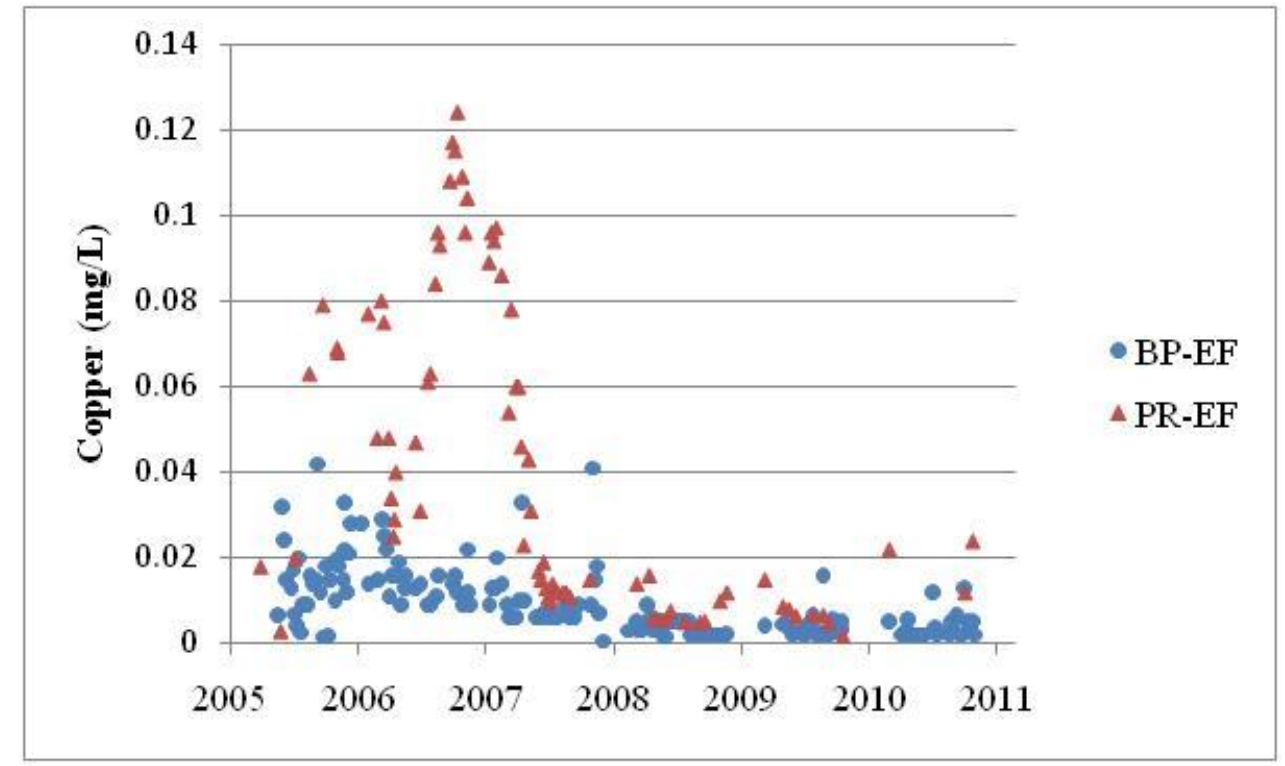

Figure 4 Copper concentrations in the tailings pond (PR-EF) and the polishing pond (BP-EF) for the 2005-2010 period

Table 1 presents $\mathrm{pH}$, copper, iron, zinc, and sulphate average values for the polishing pond effluent, the tailings pond effluent, and the 4 seepage sampling stations. Averages are calculated for the 2005-2007 and for the 2008-2010 periods. The objective is to compare average values for the first 3 years following the mine closure, and for the last three year period. Based on the compilation, metal and sulphate average values for the last three year period are all lower compared to average values for the three year post closure period, except for iron at seepage \# 3. pH values remain steady.

Regarding higher iron values at seepage \# 3, the increase is not related to ARD. Surface and groundwater of the surroundings are known to contain naturally high iron concentrations. The increase of iron at seepage \# 3 is therefore ascribed to a natural phenomenon.

Other metals are not discussed; however, their concentrations remain below Quebec surface water quality criteria (acute toxicity). 
Table 1 Surface water quality at the tailings pond (average values)

\begin{tabular}{lcccccc}
\hline Sampling Station & Period & $\mathbf{p H}$ & $\begin{array}{c}\mathbf{C u} \\
(\mathbf{m g} / \mathbf{L})\end{array}$ & $\mathbf{F e}(\mathbf{m g} / \mathbf{L})$ & $\mathbf{Z n}(\mathbf{m g} / \mathbf{L})$ & $\begin{array}{c}\text { SO4 } \\
(\mathbf{m g} / \mathbf{L})\end{array}$ \\
\hline Directive 019 surface water & & $6-9.5$ & 0.3 & 3 & 0.5 & \\
Tailings pond effluent & $2005-2007$ & 7.06 & 0.055 & 0.226 & 0.371 & 788 \\
& $2008-2010$ & 7.53 & 0.010 & 0.104 & 0.123 & 185 \\
Polishing pond final effluent & $2005-2007$ & 7.73 & 0.014 & 0.249 & 0.024 & 487 \\
& $2008-2010$ & 7.51 & 0.004 & 0.137 & 0.016 & 187 \\
Seepage \# 1 (west of TP) & $2005-2007$ & 6.74 & 0.010 & 3.230 & 0.172 & 924 \\
& $2008-2010$ & 6.92 & 0.002 & 2.770 & 0.005 & 344 \\
Seepage \# 2 (west of TP) & $2005-2007$ & 7.55 & 0.008 & 0.101 & 0.007 & 278 \\
& $2008-2010$ & 7.59 & 0.002 & 0.066 & 0.005 & 125 \\
Seepage \# 3 (north of TP) & $2005-2007$ & 6.74 & 0.010 & 0.960 & 0.011 & 983 \\
& $2008-2010$ & 6.95 & 0.002 & 1.310 & 0.006 & 274 \\
Seepage \# 4 (north of TP) & $2005-2007$ & 7.52 & 0.009 & 0.051 & 0.010 & 801 \\
& $2008-2010$ & 7.50 & 0.002 & 0.050 & 0.006 & 310 \\
\hline
\end{tabular}

Regarding groundwater quality criteria, values are compared to alert thresholds defined by the Directive 019 on mining industry as 50\% of the resurgence limits listed in appendix 2 of the Quebec Soil Protection and Contaminated Site Rehabilitation Policy (MENV, 1999).

Since mine closure in 2005, groundwater wells have been sampled twice per year and three times in 2010. Table 2 shows average values for $\mathrm{pH}$, copper, iron, zinc and sulphates for year 2010. All values are below alert thresholds.

Table 2 Groundwater quality for 2010 (average values)

\begin{tabular}{lccccc}
\hline Well & $\mathbf{p H}$ & $\mathbf{C u}(\mathbf{m g} / \mathbf{L})$ & $\mathbf{F e}(\mathbf{m g} / \mathbf{L})$ & $\mathbf{Z n}(\mathbf{m g} / \mathbf{L})$ & SO4 (mg/L) \\
\hline Alert threshold & $6-9.5$ & 0.004 & - & 0.034 & - \\
PBR-4 (north of TP) & 6.31 & 0.001 & 2.557 & 0.009 & 173 \\
PBR-6 (west of TP) & 8.46 & 0.001 & 0.030 & 0.008 & 1.2 \\
PBR-7 (west of TP) & 6.84 & 0.001 & 14.333 & 0.006 & 780 \\
PBR-8 (south of TP) & 7.84 & 0.001 & 0.242 & 0.005 & 2.2 \\
PO-06-30 (north of PP) & 6.95 & 0.001 & 0.044 & 0.005 & 22 \\
PO-06-31 (north of TP) & 7.08 & 0.001 & 0.073 & 0.006 & 88 \\
\hline
\end{tabular}

\section{Comments on the tailings pond long-term maintenance and monitoring}

The challenge with the Louvicourt tailings is maintenance in perpetuity with the risk associated with maintaining a water pond to control ARD. Teck Resources Limited believes this liability to be acceptably low considering the emphasis placed upon design and construction as well as the routine ongoing monitoring of the facility. The tailings pond is a robust infrastructure built to ensure its durability. Inspections remain a proactive measure to prevent damage to the dikes. Among others, vegetation removal on dikes and control of beaver activity to keep water management structures functional are ongoing activities. 
The annual cost for the monitoring and maintenance program varies between $\mathrm{C} \$ 150,000$ and $\mathrm{C} \$ 200,000$.

\section{Conclusion}

Louvicourt Mine ceased its commercial production in 2005 following exhaustion of its mineral reserves. A formal closure process, in compliance with Quebec Environment Quality Act, was followed. The site was rehabilitated by excavating and confining $142,000 \mathrm{~m}^{3}$ of sand and gravel backfill, contaminated mostly by copper and zinc dust coming from routine handling of waste, ore and concentrate, and of weakly acidgenerating waste rock.

The Louvicourt tailings pond was designed to control ARD by disposing milling residues under a one metre water cover within a man-made pond, with no additional remediation needed at closure. Five years after the mine closure, data from monitoring of surface and groundwater confirm that submergence of the Louvicourt tailings is a very efficient method of preventing ARD. The final effluent and seepage water quality is in compliance with Quebec surface water quality criteria (acute toxicity). Groundwater shows no indication of deterioration. Copper and zinc values within the tailings pond have gradually decreased over time since closure and are in compliance with the requirements of Directive 019.

The challenge with the Louvicourt tailings remains the maintenance in perpetuity. It is expected that portions of the site can be returned to the Crown following a period of monitoring with acceptable results.

\section{Acknowledgements}

The Louvicourt Mine closure involved a team of individuals from the Louvicourt Mine, Aur Resources Inc., Teck Resources Limited, Novicourt Inc., and Golder Associates Ltd. Thanks are due to all those people that participated in this mine closure and to those individuals who participated in the design and permitting of the mine. This paper is dedicated to the memory of Rick Firlotte from Golder Associates, who actively participated in the design and permitting.

\section{References}

Golder Associés Ltée. (2010a) Travaux de réhabilitation environnementale du site de la Mine Louvicourt excluant la rampe de Colombière, Val-d'Or, Québec, 28 p.

Golder Associés Ltée. (2010b) Évaluation environnementale de site phases I et II du parc à résidus miniers de Mine Louvicourt, Val-d'Or, Québec, 82 p.

Golder Associés Ltée. (2007a) Évaluation environnementale de site Phase III, Mine Louvicourt, Val-d'Or, Québec, $55 \mathrm{p}$.

Golder Associés Ltée. (2007b) Plan de réhabilitation, Mine Louvicourt, Val-d'Or, Québec, 36 p.

Julien, M.R., Lemieux, M., Cayouette, J. and Talbot, D. (2003) Performance and Monitoring of the Louvicourt Mine Tailings Disposal Area, $21 \mathrm{p}$.

Ministère de l'Environnement du Québec (MENV) (1999) Politique de protection des sols et de réhabilitation des terrains contaminés. Québec: Les Publications du Québec, 124 p. Ministère de l'Environnement du Québec.

MDDEP (2005) Ministère du Développement durable, de l'Environnement et des Parcs du Québec. Directive 019 sur l'industrie minière. Gouvernement du Québec, $101 \mathrm{p}$.

MDDEP (2009) Ministère du Développement durable, de l'Environnement et des Parcs du Québec. Critères de qualité de l'eau de surface. Site Web.

Yanful, E.K., Samad, M. and Mian, H. (2004) Shallow Water Cover Technology for Reactive Sulphide Tailings Management. Geotechnical News, pp. 42-51. 